\title{
On moss genera Hylocomiadelphus Ochyra \& Stebel and Rhytidiadelphus (Limpr.) Warnst.
}

Michael S. Ignatov, Elena A. Ignatova, Oxana I. Kuznetsova \& Vladimir E. Fedosov

On moss genera Hylocomiadelphus Ochyra \& Stebel and Rhytidiadelphus (Limpr.) Warnst. - Acta Mus. Siles. Sci. Natur., 68: 123-134, 2019.

\begin{abstract}
The moss family Hylocomiaceae is studied for the generic level taxonomy within a molecular phylogenetic approach. We confirm segregating of the species formerly known as Rhytidiadelphus triquetrus to Hylocomiadelphus Ochyra \& Stebel from the genus Rhytidiadelphus. Hylocomiadelphus forms a clade with Loeskeobryum and Meteoriella, sharing with both genera cordate to auriculate leaf bases and non-squarrose leaves, and with the former undulate leaves and reticulate exostome teeth ornamentation. However, Loeskeobryum differs from Hylocomiadelphus in having paraphyllia, while Meteoriella has a straight capsule and reduced peristome, likely caused by its epiphytic ecology. In the group of species closely related to $R$. squarrosus, in addition to $R$. subpinnatus, the third species with North Pacific distribution is described as R. pacificum. Macrothamnium is found deeply nested in Rhytidiadelphus, although no nomenclatural implications are suggested at the moment due to insufficient sampling. Hylocomium splendens var. splendens and var. obtusifolium were found intermingled in the phylogenetic tree, indicating no correlation between morphology and variation in ITS region, thus supporting a view that these taxa are merely environmentally induced morphs.
\end{abstract}

Key words: bryophytes, Rhytidiadelphus, Hylocomiadelphus, Hylocomium, Hylocomiaceae, taxonomy, molecular phylogeny, phytogeography, new species, new genera, nomenclature

\section{Introduction}

Despite that the moss family Hylocomiaceae M. Fleisch. is rather small, with 50-70 species worldwide, its systematics at both the generic and species level remains the point of disagreements, as well as the family circumscription itself. The comprehensive revision of Hylocomiaceae has been done by Rohrer (1985a, 1985b), and later it was the focus of morphological cladistic analysis by Hedenäs (2004). It is not surprising that subsequent molecular phylogenetic studies suggested some alternatives for the family systematics, similarly to those in many other bryophyte groups (Ignatov \& Huttunen 2002; Olsson et al. 2011; Fedosov et al. 2016). For example, Rhytidium rugosum (Hedw.) Kindb. included by Rohrer in the family has subsequently been found unrelated to it (Tsubota et al. 2004; Gardiner et al. 2005). Also, already early molecular results, e.g. Gardiner et al. (2005) found a rather distant position of Rhytidiadelphus triquetrus (Hedw.) Warnst. from other species of this genus. Basing on these results, Ignatov \& Ignatova (2004) suggested to split Rhytidiadelphus (Limpr.) Warnst. and to segregate $R$. squarrosus (Hedw.) Warnst. and related taxa in the genus Rhytidiastrum Ignatov \& Ignatova, considering typificatation of the genus Rhytidiadelphus by R. triquetrus (Abramov \& Savicz-Lyubitskaya 1963). Doing this, Ignatov and Ignatova, however, overlooked earlier lectotypification of the genus Rhytidiadelphus by $R$. squarrosus (Grout, 1928). Therefore, Ochyra \& Stebel (2008) described the new genus Hylocomiadelphus Ochyra \& Stebel for H. triquetrus. This suggestion remains not widely accepted (Huttunen et al. 2012; Rohrer 2014), so the main aim of the present study was to obtain robust evidence for or against such a segregation. 
In the present study, we concentrated on the phylogeny within the core Hylocomiaceae, i.e. Hylocomium Schimp., Hylocomiastrum M. Fleisch. ex Broth., Rhytidiadelphus, and Loeskeobryum M. Fleisch. ex Broth., supplementing new sequences with relevant data from Genbank for other genera of Hylocomiaceae (as defined by Rohrer 1985b). Species of Antitrichiaceae Ignatov and Ignatova and Climaciaceae Kindb. were added as representatives of families often considered as closely related to Hylocomiaceae. For Rhytidiadelphus and Hylocomium species we studied specimens from a broad geographical range in order to exclude possible influence from marginal haplotypes. It also made possible to address, besides the main focus of the study, two other problems in the taxonomy of Hylocomiaceae around Rhytidiadelphus squarrosus and Hylocomium splendens (Hedw.) Schimp.

\section{Material and Methods}

Internal spacers of nuclear ribosomal operon (ITS 1 and ITS2) were chosen as quickly evolving markers which provide a suitable signal to resolve phylogeny of pleurocarpous mosses on both itrageneric and intergeneric levels and thus is successfully used in other groups, combined with other markers or alone (Olsson et al. 2009; Ignatov \& Milyutina 2010; Ignatov et al. 2007, 2014; Ignatova et al. 2017). For ITS region the laboratory protocol was essentially the same as in previous moss studies, described in detail by, e.g., Gardiner et al. (2005). The dataset includes 66 sequences from 18 species of Hylocomiaceae, 43 of them newly obtained, the specimen data is given in Table 1. Sequences were aligned manually in Bioedit (Hall 1999). Climacium dendroides and Pleuroziopsis ruthenica were used as outgroup, as representatives of a closely related family Climaciaceae, often discussed along with Hylocomiaceae (Hedenäs 2004). Alignment of 825 positions was divided in three partitions, ITS1, 5.8rRNA gene and ITS2. Best-scoring Maximum Likelihood (ML) trees were estimated using RaxML 8.2.10 (Stamatakis 2006) from 1000 independent searches each starting from distinct random trees. Robustness of the nodes was assessed using the thorough bootstrapping algorithm (Felsenstein 1985) with 1000 iterations. Bayesian Analyses (BA) were performed in MrBayes 3.2.6 (Ronquist et al. 2012) with each run consisted of six Markov chains and 10,000,000 generations. The sampling frequency was one tree each 2500 generations, and the chain temperature was set at 0.02 in all analyses. Convergence of each analysis was evaluated using Tracer1.4.1 (Rambaut \& Drummond 2007) to check that all ESS values exceeded 200. Consensus trees were calculated after omitting the first 25\% trees as burn-in. Phylogenetic analyses were performed on the Cipres Science Gateway (http:// www. phylo.org/portal2) on XSEDE. In addition, the maximum parsimony analysis was completed with Nona (Goloboff 1994) within the Winclada shell (Nixon 1999), with a bootstrap calculation with 2000 replications.

\section{Results}

The Baesyan, ML and MP trees have similar topologies, thus we present here Bayesian tree only (Fig. 1), adding support values from ML and MP analyses and discussing the difference wherever relevant. Basal grade in the tree is formed by Pleurozium schreberi (Brid.) Mitt., Antitrichia curtipendula (Hedw.) Brid. and Neodolichomitra yunnanensis (Besch.) T.J. Kop. Two latter genera are resolved in low supported clade in ML and MP trees, and form a polytomy in Bayesian analysis (Fig. 1)

Core Hylocomiaceae, i.e. Hylocomium, Hylocomiastrum, Rhytidiadelphus and Loeskeobryum are resolved in a well supported clade, which includes also Leptohymenium Schwägr., Leptocladiella M. Fleisch., Orontobryum Mitt. ex M. Fleisch., Meteoriella S. Okamura and Macrothamnium M. Fleisch. This clade is subdivided in the tree inferred from Bayesian analysis into two subclades: (1) maximally supported in Bayesian and ML analyses and with BS=99 in MP, Rhytidiadelphus sensu Ochyra \& Stebel (2008) clade, which includes also Macrothamnium, and (2) other core Hylocomiaceae-clade, with all other genera and Hylocomiadelphus triquetrus, having high to moderate support in Bayesian and ML analyses $(\mathrm{PP}=99, \mathrm{BS}=84)$, but not resolved in MP where its groups form a polytomy of smaller clades. 


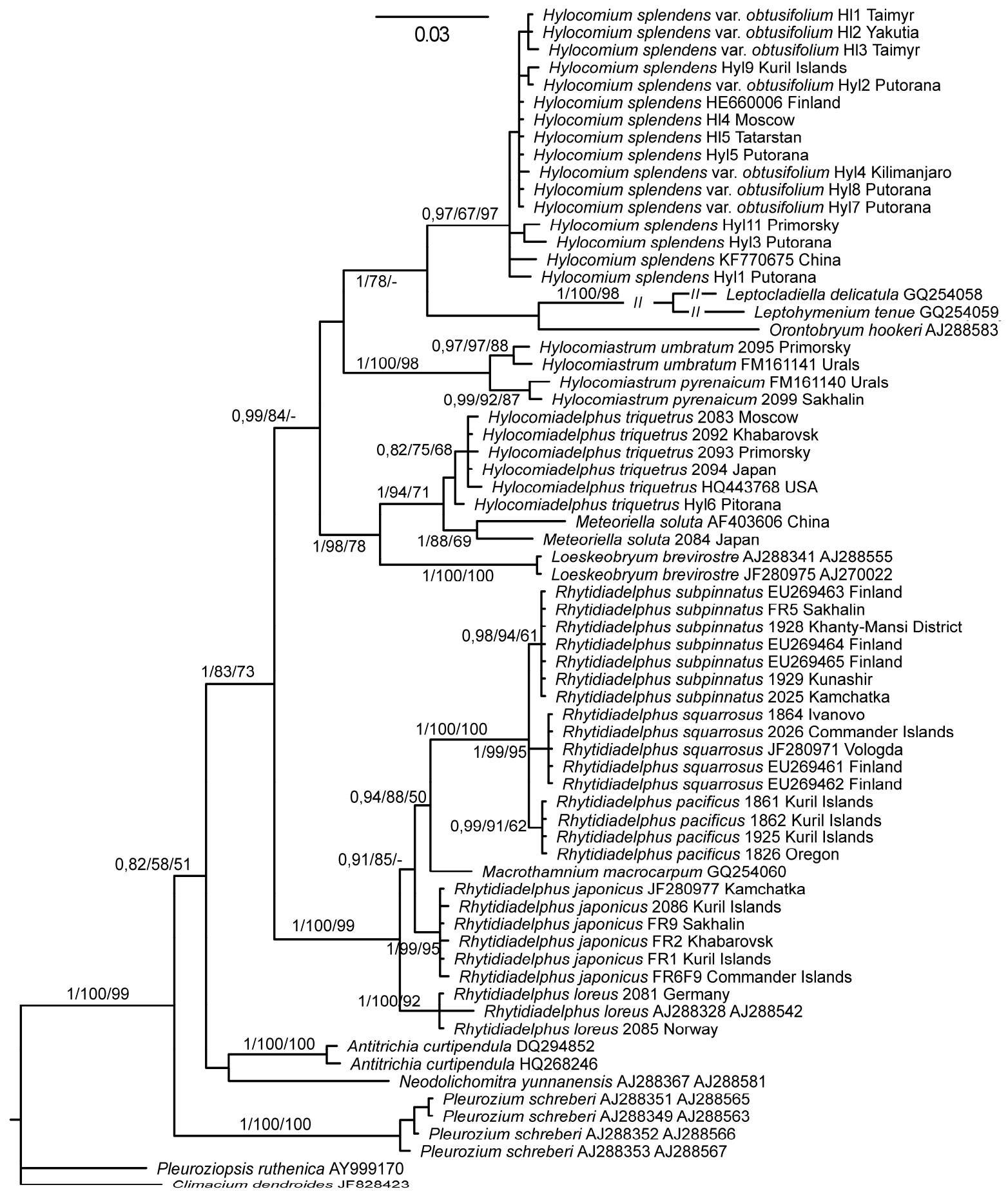

Fig 1: Bayesian tree based on nuclear ITS sequences. Support values are shown at branches: Bayesian posterior probability / ML bootstrap support / MP bootstrap support.

The topology of Rhytidiadelphus-clade is almost the same in all analyses: it includes the grade of $R$. loreus (Hedw.) Warnst., R. japonicus (Reimers) T.J. Kop., Macrothamnium macrocarpum (Reinw. \& Hornsch.) M. Fleisch., and terminal clade of $R$. subpinnatus (Lindb.) T.J. Kop., R. squarrosus and a new species described below, $R$. pacificum. Support for the clades of three latter species is moderate to low, although visual analysis of the alignment ensures that these three entities have stable differences (Fig. 2). Altogether species of $R$. squarrosum-group 
share 11 substitutions and one indel of $2 \mathrm{bp}$, differing them from both $R$. loreus and $R$. japonicus. Each of three clades within $R$. squarrosus-group also has unique substitutions: $R$. squarrosus has three, new species two, and $R$. subpinnatus one (Fig. 2). Since $R$. squarrosus and $R$. subpinnatus are represented by specimens from West Europe to Pacific coast, such distinction has to be considered as very stable. The third species includes sequenced specimens also from areas nearly $8000 \mathrm{~km}$ one from another, thus its two substitutions in ITS and morphological differentiation seems no less sound than between $R$. squarrosus and $R$. subpinnatus, thus requiring the same status of a separate species, not just as a locally presented haplotype.

Larger subclade of Hylocomiaceae in Bayesian and ML analyses has identical topology of two further subclades: one with Hylocomiastrum+Orontobryum+Leptocladiella+Leptohymenium+Hylocomium, and another formed by Loeskeobryum+Hylocomiadelphus+Meteoriella. The former clade has poor support as a whole, but its subclades formed by species of Hylocomiastrum and Hylocomium have a rather high support.

The Loeskeobryum+Hylocomiadelphus + Meteoriella clade is maximally to highly supported in all analyses ( $\mathrm{PP}=1, \mathrm{ML} \mathrm{BS}=98, \mathrm{MP} \mathrm{BS}=78)$. Within this clade Loeskeobryum keeps basal position, while Hylocomiadelphus forms a clade with Meteoriella with high to low support (PP=1, ML BS=94, MP BS=71).

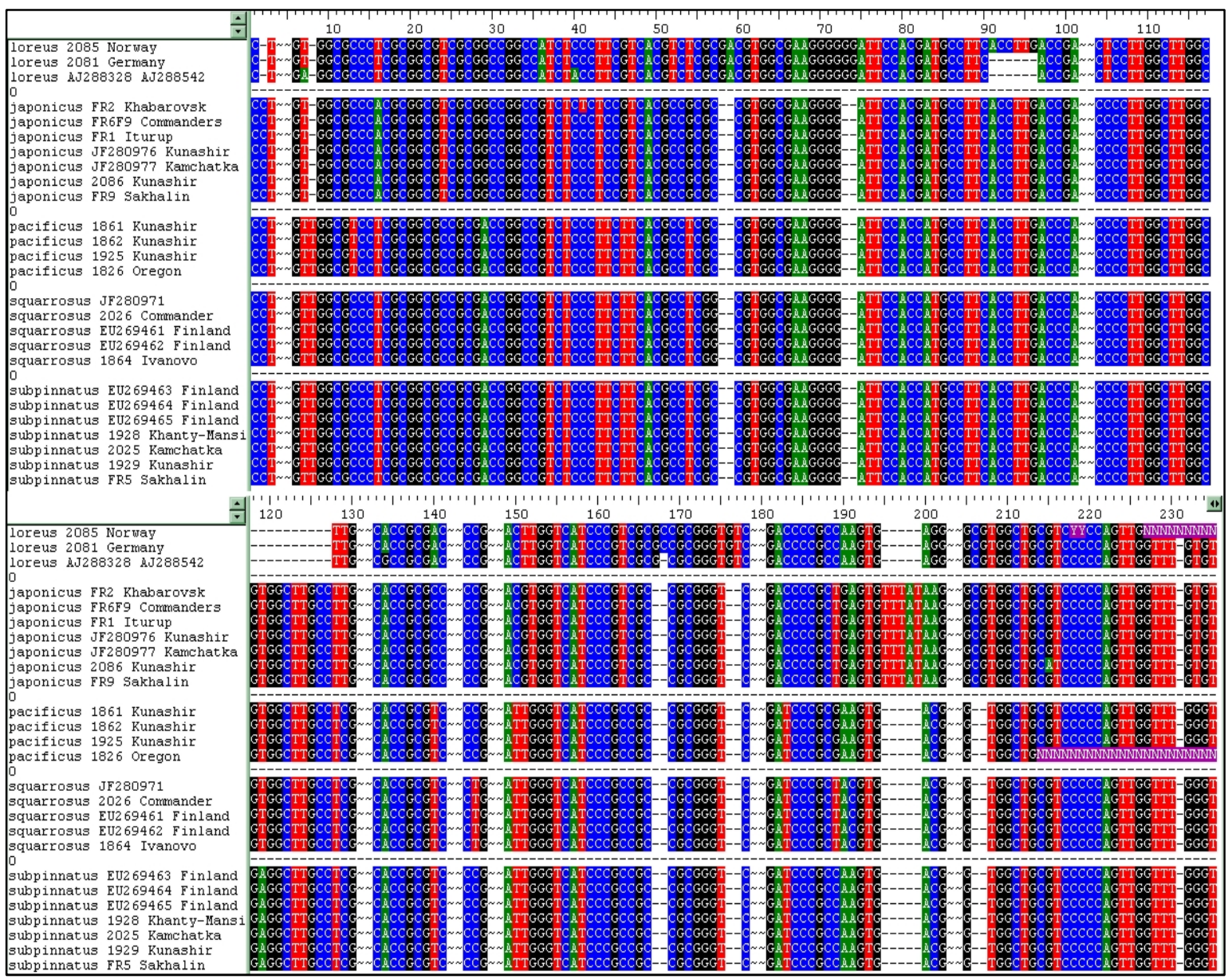

Fig 2: Parts of nuclear ITS alignment of five species of Rhytidiadelphus, with omitted invariable parts, substituted by double space columns. 


\section{Discussion}

\section{Phylogenetic position of Hylocomiadelphus triquetrus}

The present analysis do not contradict previously published molecular phylogenetic analyses, although the latter were generally less complete, and therefore can be compared only by parts (Chiang \& Schaal, 2000; Vanderpoorten et al., 2003; Tsubota et al., 2004; Gardiner et al., 2005; Ignatov et al., 2007; Wang et al., 2010; Cox et al., 2010; Huttunen et al., 2012). Poor sampling in previous studies likely was the main reason why Hylocomiadelphus triquetrus continued to be accepted in the genus Rhytidiadelphus, despite molecular phylogenetic analysis that mildly indicated the opposite. The present analysis unequivocally supports the acceptance of the genus Hylocomiadelphus Ochyra \& Stebel.

Our data also point that the closest relative of Hylocomiadelphus is Loeskeobryum brevirostre (Brid.) M. Fleisch.; it shares with Hylocomiadelphus rigid, erect, non-reflexed leaves, which are plicate and undulate, have auriculate base and long double costa reaching beyond the mid-leaf, as well as reticulate ornamentatation of exostome teeth from outside.

Obviously, the presence of paraphyllia was a character which was thought to be of crucial importance for a long time. It can be reminded that less than 40 years ago in the Check-list of mosses of Europe by Corley et al. (1981), all the Hylocomiaceae with paraphyllia were classified in just one genus Hylocomium, and only after the revision by Rohrer (1985a, 1985b) this genus was split, and molecular data now fully support that it is reasonable. Hylocomium s.str., Hylocomiastrum and Loeskeobryum do not form a clade (Fig. 1), but are intermingled in clades with genera without paraphyllia: Loeskeobryum forms a clade with eparaphyllose Meteoriella and Hylocomiadelphus, while between Hylocomiastrum and Hylocomium are eparaphyllose Leptohymenium and Leptocladiella, and not always paraphyllose Orontobryum.

It might be worth noting that in the Climaciaceae, a family sharply delimited morphologically by dendroid plant habit, as in of Climacium and Pleuroziopsis, molecular phylogeny also revealed a subaquatic plant, formerly classified as a Hygrohypnum or Leptodictyum; it was independently resolved within Climaciaceae by three molecular markers, and thus placed within the family despite of average hypnoid habit (Ignatov et al., 2014).

The genus Meteoriella was found even closer to Hylocomiadelphus in all analyses, however, this tropical epiphytic plant has strongly deviated morphology, especially in sporophyte structure, and only auriculate leaf base seems to be a character shared by three genera forming this clade, i.e. Loeskeobryum, Meteoriella and Hylocomiadelphus. The cases when molecular markers reveal the relationship between epiphytic genera and terrestrial genera of "average" morphology were found recently in many phylogenetic lineages (Huttunen et al., 2004, 2012), providing highly unexpected examples of rapid modification of sporophytes, and the pair Meteoriella+Hylocomiadelphus is one more such example. Therefore the conclusion by Hedenäs (2004) about the important differentiation of tropical and temperate lineages related to Hylocomiaceae has to be reconsidered, especially concerning the position of Leptocladiella, Leptohyme-nium and Macrothamnium, also found intermingled with common boreal mosses.

\section{Taxonomy of Rhytidiadelphus squarrosus complex}

There is a noteworthy discreapancy between European and American taxonomists in their approaches to $R$. squarrosus and $R$. subpinnatus complex. In Europe, the latter species was recognized for a long time as $R$. squarrosus var. calvescens (Lindb.) Warnst., but it was almost invariably mentioned in treatments; e.g., Limpricht (1896) included it in the general key for species. Koponen (1971) clearly described the difference between $R$. squarrosus and $R$. subpinnatus and introduced the species status of the latter. Contrary to this, Grout (1928), Crum \& Anderson (1981) and Rohrer (1985b) stated that in North America this variety and, later, species, $R$. subpinnatus, can not always be successfully separated, or even it was not 
mentioned at all (Lawton, 1971). Later Rohrer (2014) accepted $R$. subpinnatus as a species, basing on molecular evidence published by Vanderpoorten et al. (2003) and Korpelainen et al. (2008), although still noting that sometimes these species are difficult to distinguish by morphology. Although the latter is sometimes difficult, we presume that this view of North American bryologists may be partly explained also by the presence of the third species revealed in our molecular analysis. Below is its description.

\section{Rhytidiadelphus pacificus Ignatov, Ignatova \& Fedosov, sp. nova}

Type: Russia, Sakhalinskaya Province, Kuril Islands, Kunashir Island, 2 km north of Yuzhno-Kurilsk, $44^{\circ} 3^{`} \mathrm{~N}$, $145^{\circ} 50$ 'E, $10 \mathrm{~m}$ alt., on dunes at sea shore, 9.IX.2006, Ignatov 06-3207 (holotype MHA9049126). Figs. 3-12, 14, 16,17 .

Diagnosis: Rhytidiadelphus pacificus differs from $R$. subpinnatus in having irregularly branched stems and more densely arranged stem leaves with ovate vs. triangular basal part; it differs from $R$. japonicus by more densely arranged stem leaves with longer acumens, shorter costae and thin- vs. thick-walled alar cells; the differences from $R$. squarrosus include sharply differentiated stem and branch leaves; it also differs from all three species in having very finely serrulate vs. serrate margins of stem and branch leaves and by nuclear ITS sequence as shown in Fig. 2.

Etymology: the species indicates the distribution of the species along the coast of Pacific Ocean both in Asia and North America.

Description: Plants in loose mats, light green, slightly glossy. Stems ascending, to $15 \mathrm{~cm}$ long, $4 \mathrm{~mm}$ wide with leaves, irregularly branched, branches to $1.5 \mathrm{~cm}$ long, stem reddish-brown, in transverse section 5-angled, without hyalodermis, with 1-2-layered sclerodermis formed by cells with moderately thickened, brown-colored walls, thin-walled medullar cells and indistinct central strand consisting of few smaller cells. Stem leaves crowded, more or less sheathing, stem hardly visible between them, widely spreading to reflexed, 2.5-3.7 × 1.0-1.7 mm, from broadly ovate base abruptly narrowed into long acumen, widely rounded to the insertion, not plicate or undulate; margins very finely serrulate almost throughout; costa double, ca. 1/4 the leaf length; median leaf cells 55-80 $\times$ 6-7 $\mu \mathrm{m}$, with moderately thickened, weakly porose walls; alar cells differentiated, rectangular, 15-17 $\mu \mathrm{m}$ wide, thin-walled, forming quadrate or rectangular group not reaching the costa. Branch leaves sharply differentiated from stem leaves, erect-spreading, not sheathing, ovate-lanceolate, $2.0-2.3 \times 0.5-0.75 \mathrm{~mm}$, margins finely serrulate. Dioicous. Only female plants seen. Outer perichaetial leaves ovate, $1.0-1.3 \times 0.4-0.6 \mathrm{~mm}$, inner perichaetial leaves longer, sharply reflexed at their middle, $1.5-2.0 \times 0.5-0.6 \mathrm{~mm}$, ecostate, with fine serrulation in mid-leaf, at area of maximal curvation. Male plants and sporophytes not seen.

Distribution and ecology: According to label information and personal observation, in Kunashir Island R. pacificus grows on soil in boggy meadows and on dunes covered with grass vegetation at sea shore, at altitude 4-10 m, while in Oregon it was collected at elevation $350 \mathrm{~m}$, in coniferous forest (Abies concolor, Tsuga heterophylla and Pseudotsuga), on diffusely lit soil layer over outcrops. Presumably the species occurs also in Japan, at least an illustration of $R$. subpinnatus in Noguchi (1994) much better fits $R$. pacificus, than $R$. subpinnatus.

Specimens examined: Russia: Sakhalinskaya Province, Kunashir Island, Lagunnoe Lake, 44³'4”N, 14548'4'E. $4 \mathrm{~m}$ alt., 15.VIII.2015 Koroteeva 15-12-1 (MHA 9049129); same place, Koroteeva 15-12-8 (MHA9049128). U.S.A., Oregon, Linn Co., 1 mile north of US Forest Service Road 11 (2 miles west of Quartzville), 44³3’N, $122^{\circ} 23^{\prime}$ W, Willamette National Forest, 4.X.1994 Norris 83956 (MHA9057426).

Rhytidiadelphus pacificus shares with $R$. squarrosus crowded, more or less sheathing leaves with ovate base and reflexed acumina; however, its branch leaves are more similar to those of $R$. subpinnatus and $R$. japonicus, since they are not similar to stem leaves - not sheathing, with straight apices, erect-spreading. At the same time, $R$. pacificus has crowded and sheathing stem leaves with an ovate base, while stem leaves of $R$. subpinnatus are more distantly arranged, not sheathing and have a triangular basal part. Rhytidiadelphus pacificus is also distinct from $R$. japonicus because this species has a shorter acumen in stem leaves, which are also distantly arranged, have longer costae and thick-walled alar cells. In addition, leaf margins of both stem and branch leaves of $R$. pacificus are only faintly serrulate, while they are sharply serrate in all three other species. 


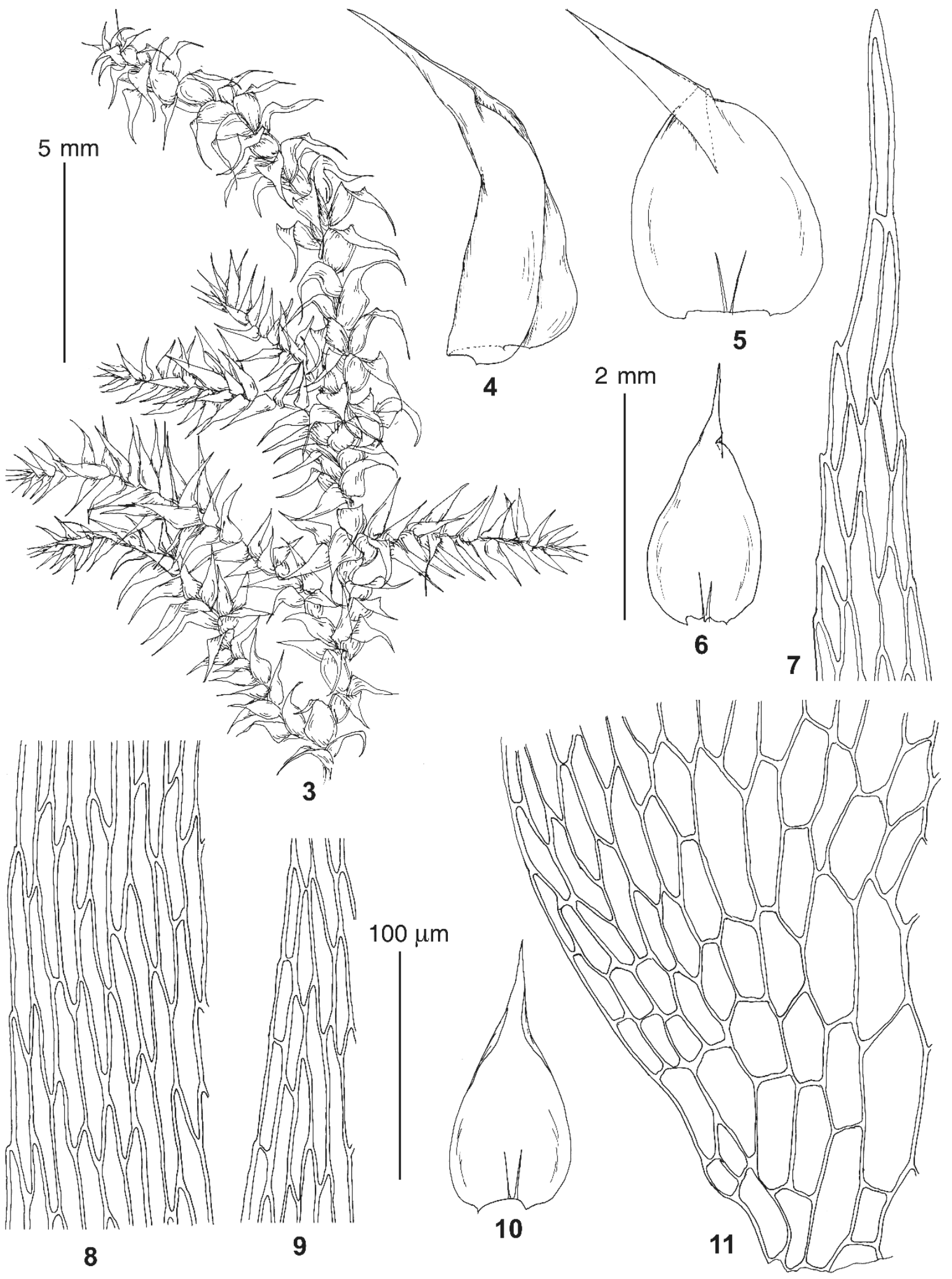

Figs 3-11: Rhytidiadelphus pacificus (from holotype): 3: habit; 4-5: stem leaves; 6 \& 10: branch leaves; 7: apical cells; 8-9: median leaf cells; 11: basal leaf cells. 

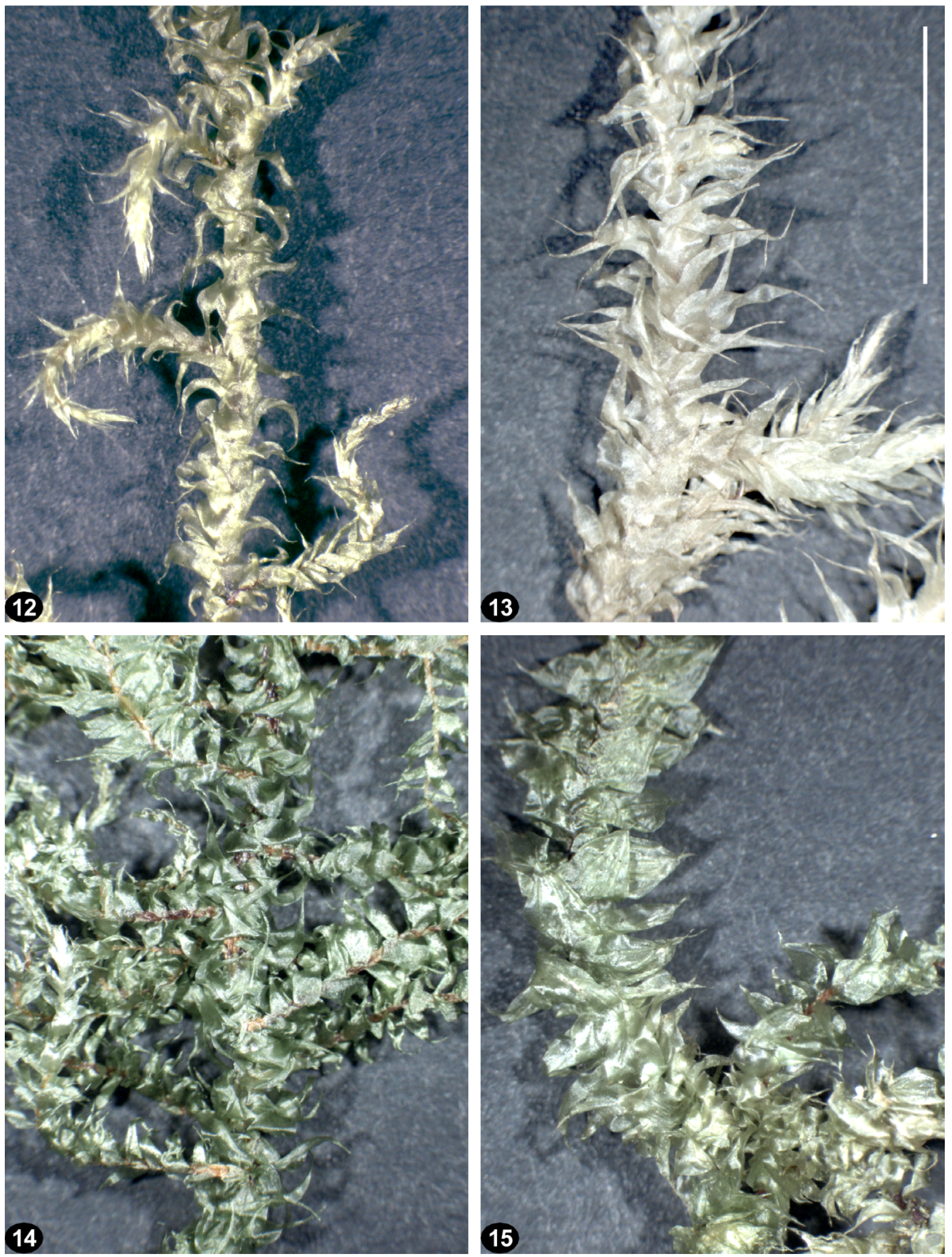

Figs 12-15: Photo of four species of Rhytidiadelphus: 12: R. squarrosus (European Russia, Ivanovo, Sorokin, coll. 27.VI.2008 MHA); 13: $R$. pacificus (holotype); 14: R. subpinnatus (Primorsky Territory, Olchovaya Mt., Ignatov et al., 06-2319, MHA); 15: R. japonicus (Kuril Islands, Ignatov et al., 06-1437, MHA). Scale bar 5 mm for all. 


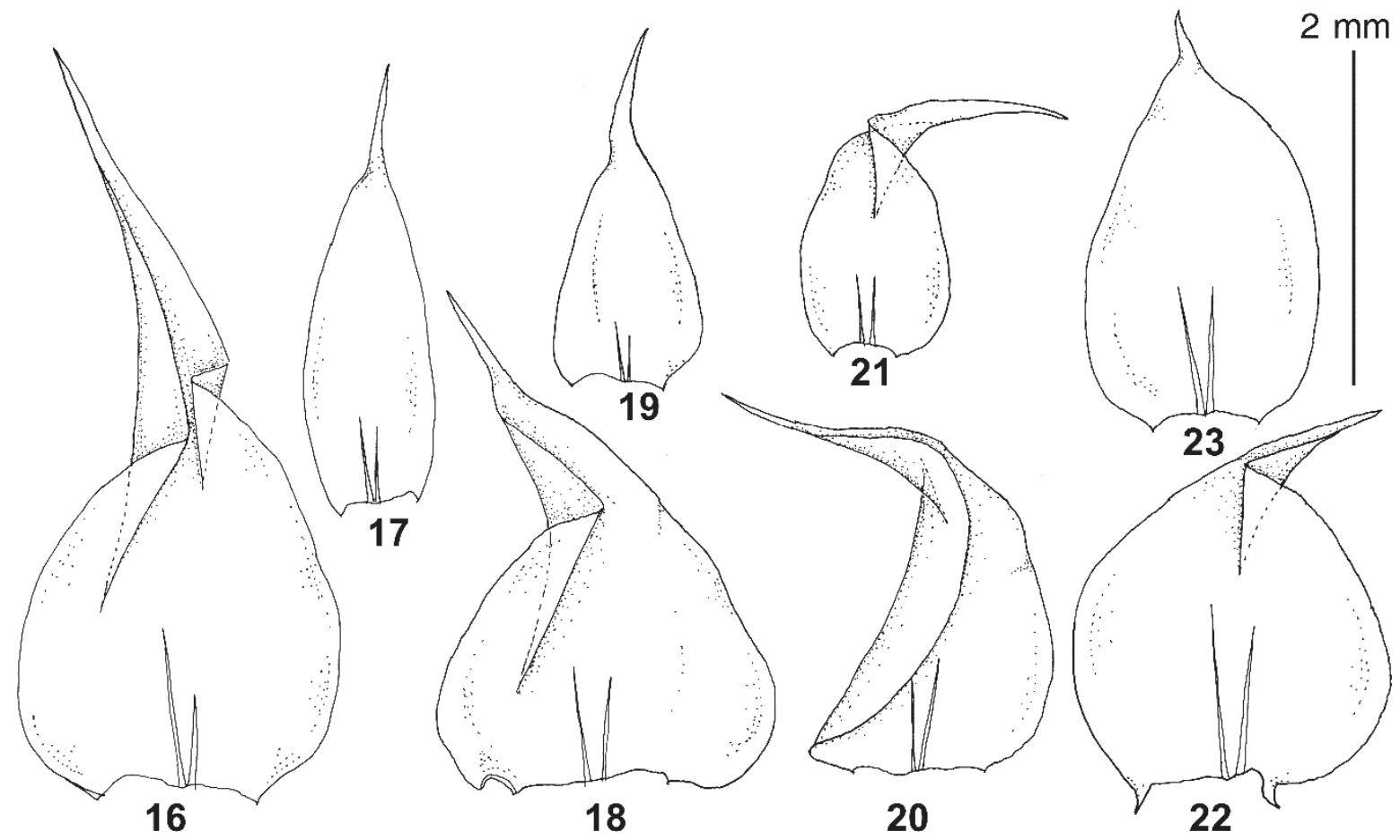

Figs 16-23: Stem $(16,18,20,22)$ and branch $(17,19,21,23)$ leaves of four species of Rhytidiadelphus: 16-17: R. pacificus (holotype); 18-19: R. subpinnatus (Primorsky Territory, Olchovaya Mt., Ignatov et al., 06-2319, MHA); 20-21: $R$. squarrosus (Ivanovo, European Russia, Sorokin, coll. 27.VI.2008 MHA); 22-23: R. japonicus (Kuril Islands, Ignatov et al., 06-1437, MHA). Scale bar $2 \mathrm{~mm}$ for all.

\section{Key to identification of Rhytidiadelphus species in Russia}

1. Leaves plicate, at stem and branch apices falcate-secund; alar cells not differentiated R. loreus

1. Leaves not plicate, not falcate-secund; alar cells clearly differentiated

2. Costa reaching 1/3-1/2 the leaf length; alar cells thick-walled; leaf acumens comparatively short

2. Costa reaching not longer than $1 / 3$ the leaf length; alar cells thin-walled; leaf acumens long

R. japonicus

3. Branch and stem leaves similar, crowded, with spreading to reflexed acumina

R. squarrosus

3. Stem leaves crowded or distant, with reflexed acumina, branch leaves sharply differentiated, erectspreading, with straight acumina

4. Stem leaves crowded, stem hardly visible between them; basal part of stem leaves ovate; margins of stem and branch leaves faintly serrulate

R. pacificus

4. Stem leaves more or less distant, stem visible between them at places; basal part of stem leaves triangularovate; margins of stem and branch leaves sharply serrate

R. subpinnatus

3. Hylocomium splendens (Hedw.) Schimp. var. splendens and var. obtusifolium (Geh.) Paris (=H. alaskanum (Lesq. \& James) Austin).

Most authors accepted these taxa as varieties, although Grout (1928) argued for the species status of $H$. alaskanum. The latter is an Arctic and high mountain taxon, differing from the type variety in branching pattern and stem leaf shape. On Putorana Plateau, vicinity of Sobach'e Lake this morphotype is common above the timberline, whereas within forest belt Hylocomium splendens s. str. occurs. Three specimens of these phenotypes from Putotana were compared with each other, as well as with a number of morphologically similar plants from other regions, from high Arctic to Kilimanjaro Mt. Although ITS sequences in H. splendens s.l. were found to be variable, their variation does not correlate with morphology of var. obtusifolium and 
var. splendens. Furthermore, plants of different haplotypes grow in Putorana together. These results support a view that var. obtusifolium is merely an environmentally induced morph of H. splendens.

Acknowledgements: We are grateful to Dr. Ryszard Ochyra for consulatations in nomenclatural question and providing a Tanzanian collection for this study and to James Shevock for English correction. The work of MI and OK was conducted under institutional project №118021490111-5, of EI under AAAA-A16-116021660039-1, of VF under RFBR 18-05-60093.

\section{References}

Abramov I.I. \& Savicz-Lyubitskaya L.I. (1963): Division Bryopsida. In: Orlov, Yu.A. (ed.) Osnovy Paleontologii. Moscow, Gosgeoltekhizdat. Volume "Vodorosli, mkhi, psilophyty, plaunovye, chlenistostebelnye, paporotniki", pp. 344-414. (in Russian).

Chiang T.Y. \& Schaal B.A. (2000): The internal transcribed spacer 2 region of the nuclear ribosomal DNA and the phylogeny of the moss family Hylocomiaceae. - Plant Systematics and Evolution 224: 127-137.

Corley M.F.V., Crundwell A.C., Düll R., Hill M.O. \& Smith A.J.E. (1981): Mosses of Europe and the Azores: an annotated list of species, with synonyms from the recent literature. - Journal of Bryology 11: 609689.

Cox C.J., Goffinet B., Wickett N., Boles S.B. \& Shaw A.J. (2010): Moss diversity: a molecular phylogenetic analysis of genera. - Phytotaxa 9: 175-195.

Crum H.A. \& Anderson L.E. (1981): Mosses of Eastern North America Vol. 2. pp. 665-1328. Columbia University Press, New York.

Fedosov V.E., Fedorova A.V., Fedosov A.E. \& Ignatov M.S. (2016): Phylogenetic inference and peristome evolution in haplolepideous mosses, focusing on Pseudoditrichaceae and Ditrichaceae s. 1. - Botanical Journal of the Linnean Society 181(2): 139-155.

Felsenstein J. (1985): Confidence limits on phylogenies: an approach using the bootstrap. - Evolution 39: 783791.

Gardiner A., Ignatov M., Huttunen S. \& Troitsky A. (2005): On resurrection of the families Pseudoleskeaceae Schimp. and Pylaisiaceae Schimp. (Musci, Hypnales). - Taxon 54: 651-663.

Goloboff P.A. (1994): NONA: A tree searching program. Program and documentation. Argentina, Tucumán, published by the author.

Grout A.J. (1928): Moss Flora of North America. Vol. 3: 1-277. Author, Newfane, Vermont.

Hall T.A. (1999): BioEdit: a user-friendly biological sequence alignment editor and analysis program for Windows 95/98/NT. - Nuclear Acids Symposium Series 41: 95-98.

Hedenäs L. (2004): Morphological and anatomical evidence suggest that 'Hylocomiaceae' taxa belong to at least two clades. - Journal of Bryology 26: 125-135.

Huttunen S., Bell N., Bobrova V.K., Buchbender V., Buck W.R., Cox C.J., Goffinet B., Hedenäs L., Ho B.-C., Ignatov M.S., Krug M., Kuznetsova O.I., Milyutina I.A., Newton A.E., Olsson S., Pokorny Montero L., Shaw J., Stech M., Troitsky A.V., Vanderpoorten A. \& Quandt D. (2012): Disentangling knots of rapid evolution: origin and diversification of the moss order Hypnales. - Journal of Bryology 34(3): 187-211.

Huttunen S., Ignatov M.S., Müller K. \& Quandt D. (2004): Phylogeny and evolution of epiphytism in the three moss families Meteoriaceae, Brachytheciaceae, and Lembophyllaceae. - In: Goffinet B., Hollowell V.C. \& Magill R.E. (eds) Molecular systematics of bryophytes, St. Louis: Missouri Botanical Garden Press: pp. 328-355.

Huttunen S., Olsson S., Buchbender V., Enroth J., Hedenäs L. \& Quandt D. (2012): Phylogeny-based comparative methods question the adaptive nature of sporophytic specializations in mosses. - PLos One 7(10): e48268.

Ignatov M.S. \& Huttunen S. (2002): Brachytheciaceae (Bryophyta)—a family of sibling genera. - Arctoa 11: 245-296.

Ignatov M.S. \& Ignatova E.A. (2004): Flora mkhov srednei chasti evropeiskoi Rossii. Tom 2. FontinalaceaeAmblystegiaceae. Moss flora of the Middle European Russia. Volume 2: Fontinalaceae-Amblystegiaceae. Arctoa 11(Supplement 2): 609-960.

Ignatov M.S. \& Milyutina I.A. (2010): On the systematic position of the genus Sasaokaea (Bryophyta). Arctoa 19: 63-68.

Ignatov M.S., Gardiner A.A., Bobrova V.K., Milyutina I.A., Huttunen S. \& Troitsky A.V. (2007): On the relationships of mosses of the order Hypnales, with special reference to taxa traditionally classified in the Leskeaceae. In A. E. Newton \& R. S. Tangney (eds), Pleurocarpous mosses: systematics and evolution. Systematic Association Special Volume 71: 177-213. 
Ignatov M.S., Kuznetsova O.I. \& Czernyadjeva I.V. (2014): On the systematic position of Leptodictyum mizushimae (Bryophyta). - Arctoa 23: 185-193.

Ignatova E.A., Kuznetsova O.I., Milyutina I.A., Fedosov V.E. \& Ignatov M.S. (2017): The genus Fabronia (Fabroniaceae, Bryophyta) in Russia. - Arctoa 26: 11-34.

Koponen T. (1971): Rhytidiadelphus japonicus and R. subpinnatus. - Hikobia 6: 18-34.

Korpelainen H., Virtanen V., Kostamo K. \& Karttunen H. (2008): Molecular evidence shows that the moss Rhytidiadelphus subpinnatus (Hylocomiaceae) is clearly distinct from R. squarrosus. - Molecular Phylogenetics and Evolution 48(1): 372-376.

Lawton E. (1971): Moss Flora of the Pacific Northwest. Hattori Botanical Laboratory, Nichinan, Japan.

Limpricht K.G. (1896): 169. Gattung: Hylocomium Br. eur., pp. 574-600. In: Dr L. Rabenhorst's KryptogamenFlora von Deutschland, Oesterreich und der Schweiz. 2 Auflage. Vierter Band: Die Laubmoose Deutschlands, Oesterreichs und der Schweiz. III. Abtheilung: Hypnaceae). Eduard Kummer, Leipzig.

Nix on K.C. (1999): Winclada (BETA) ver. 0.9.9. Available from: http://www.cladistics.com/about winc.html (accessed 1 April 2018).

Noguchi A. (1994): (supplemented by Z. Iwatsuki \& T. Yamaguchi) Illustrated Moss Flora if Japan, Pt. 5. Hattori Botanical Laboratory, Nichinan: pp. 1013-1253.

Ochyra R. \& Stebel A. (2008): Hylocomiadelphus, a new genus of pleurocarpous mosses. In: Stebel A. \& Ochyra R. (eds), Bryophytes of the Polish Carpathians, pp. 303-308. Sorus, Poznań.

Olsson S., Buchbender V., Enroth J., Huttunen S., Hedenäs L. \& Quandt D. (2009): Evolution of the Neckeraceae (Bryophyta): resolving the backbone phylogeny. - Systematics and Biodiversity 7(4): 419-432.

Olsson S., Enroth J., Buchbender V., Hedenäs L., Huttunen S. \& Quandt D. (2011): Neckera and Thamnobryum (Neckeraceae, Bryopsida): paraphyletic assemblages. - Taxon 60(1): 36-50.

Rambaut A. \& Drummond A.J. (2007): Computer program and documentation distributed by the author, website http://beast. bio. ed. ac. uk/Tracer.

Rohrer J.R. (1985a): A phenetic and phylogenetic analysis of the Hylocomiaceae and Rhytidiaceae. - Journal of the Hattori Botanical Laboratory 59: 185-240.

- (1985b): A generic revision of the Hylocomiaceae. - Journal of the Hattori Botanical Laboratory 59: 241-278.

- (2014): Hylocomiaceae. In: Flora of North America Editorial Committee (ed.). Flora of North America, Vol 28. Oxford University Press, New York, Oxford: 325-337.

Ronquist F., Teslenko M., Mark P. van der, Ayres D.L., Darling A., Höhna S., Larget B., Liu L., Suchard M.A. \& Huelsenbeck J.P. (2012): MrBayes 3.2: efficient Bayesian phylogenetic inference and model choice across a large model space. - Systematic Biology 61: 539-542.

Stamatakis A. (2006): RAxML-VI-HPC: maximum likelihood-based phylogenetic analyses with thousands of taxa and mixed models. - Bioinformatics 22: 2688-2690.

Tsubota H., Luna E.D., González D., Ignatov M.S. \& Deguchi H. (2004): Molecular phylogenetics and ordinal relationships based on analyses of a large-scale data set of $600 \mathrm{rbcL}$ sequences of mosses. - Hikobia 14: $149-170$.

Vanderpoorten A., Hedenäs L. \& Jacquemart A. L. (2003): Differentiation in DNA fingerprinting and morphology among species of the pleurocarpous moss genus, Rhytidiadelphus (Hylocomiaceae). - Taxon 52: 229-236.

Wang Q.-H., Jia Y., Liu Y. \& Chen Z.-D. (2010): The systematic position of Meteoriella S. Okamura (Musci) based on molecular and morphological data. - Taxon 59(1): 93-100.

Authors' addresses: Michael S. Ignatov \& Oxana I. Kuznetsova, Tsitsin Main Botanical Garden of Russian Academy of Sciences, Botanicheskaya 4, Moscow 127276 Russia.

E-mail: misha_ignatov@list.ru (corresponding author), oikuznets@gmail.com

Elena A. Ignatova \& Vladimir E. Fedosov, Department of Geobotany, Faculty of Biology, Lomonosov Moscow State University, Leninskie Gory Str. 1-12, Moscow 119234 Russia.E-mail: arctoa@list.ru, fedosov_v@mail.ru 
Appendix.

Table 1: Newly sequenced specimens used in molecular phylogenetic analysis, with voucher information and GenBank accession numbers.

\begin{tabular}{|c|c|c|}
\hline Species & Vaucher data & GenBank \#\# \\
\hline Hylocomiastrum umbratum & $\begin{array}{l}\text { Russia, Primorsky, Ignatov et al. 06-2235 MHA 9037087, isolate } \\
\text { OK2095 }\end{array}$ & MK463496 \\
\hline Hylocomiastrum pyrenaicum & $\begin{array}{l}\text { Russia, Sakhalin, Ignatov \& Teleganova 06-738 MHA 9037005, } \\
\text { isolate OK2099 }\end{array}$ & MK463497 \\
\hline Hylocomiadelphus triquetrus & Russia, Putorana, Fedosov 18-01-0001 MW, isolate Hyl6 & MK463498 \\
\hline Hylocomiadelphus triquetrus & $\begin{array}{l}\text { Russia, Moscow, Grigorovo, Ignatov and Ignatova, } 11 \text { Nov } 2018 \text {, } \\
\text { MHA, isolate OK2083 }\end{array}$ & MK463499 \\
\hline Hylocomiadelphus triquetrus & $\begin{array}{l}\text { Russia, Khabarovsk, Botchi, Ignatov and Ignatova 13-50 MHA, } \\
\text { isolate OK2092 }\end{array}$ & MK463500 \\
\hline Hylocomiadelphus triquetrus & $\begin{array}{l}\text { Russia, Primorsky, Lazo, Ignatov and Ignatova 13-1392 MHA, } \\
\text { isolate OK2093 }\end{array}$ & MK463501 \\
\hline Hylocomiadelphus triquetrus & Japan, Inouga 9 Sept 2001, MHA, isolate OK2094 & MK463502 \\
\hline Meteoriella soluta & Japan, Iwatsuki 6 Dec 1979 MHA 9061907, isolate OK2084 & MK463503 \\
\hline Hylocomium splendens & Russia, Putorana, Fedosov 18-01-0005 MW, isolate Hyl1 & MK463504 \\
\hline Hylocomium splendens & $\begin{array}{l}\text { Russia, Kuril Islands, Shikotan, Bakalin 40-3-07 MW 9044945, } \\
\text { isolate Hyl9 }\end{array}$ & MK463505 \\
\hline Hylocomium splendens & $\begin{array}{l}\text { Russia, Primorsky, Ignatov et al. 06-2322 MW 9044949, isolate } \\
\text { Hyl11 }\end{array}$ & MK463506 \\
\hline Hylocomium splendens & Russia, Moscow, Kozlova, sn MW 9044694, isolate Hl4 & MK463507 \\
\hline Hylocomium splendens & $\begin{array}{l}\text { Russia, Tatarstan, Ignatov and Ignatova, } 14 \text { Aug 2003, MW } \\
\text { 9044795, isolate H15 }\end{array}$ & MK463508 \\
\hline Hylocomium splendens & Russia, Putorana, Fedosov 18-01-0004 MW, isolate Hyl3 & MK463509 \\
\hline Hylocomium splendens & Russia, Putorana, Fedosov 18-01-0003 MW, isolate Hyl5 & MK463510 \\
\hline $\begin{array}{l}\text { Hylocomium splendens var. } \\
\text { obtusifolium }\end{array}$ & Russia, Putorana, Fedosov 18-01-0002 MW, isolate Hyl2 & MK463511 \\
\hline $\begin{array}{l}\text { Hylocomium splendens var. } \\
\text { obtusifolium }\end{array}$ & Tanzania, Kilimandzharo, Ochyra sn KRAM 102388, isolate Hyl4 & MK463512 \\
\hline $\begin{array}{l}\text { Hylocomium splendens var. } \\
\text { obtusifolium }\end{array}$ & Russia, Taimyr, Meduza Fedosov MW 9045017, isolate Hyl6 & MK463513 \\
\hline $\begin{array}{l}\text { Hylocomium splendens var. } \\
\text { obtusifolium }\end{array}$ & Russia, Yakutia, Orulgan Ignatov MW 9045029, isolate H12 & MK463514 \\
\hline $\begin{array}{l}\text { Hylocomium splendens var. } \\
\text { obtusifolium }\end{array}$ & Russia, Taimyr, Byrranga Fedosov MW 9045024, isolate H13 & MK463515 \\
\hline $\begin{array}{l}\text { Hylocomium splendens var. } \\
\text { obtusifolium }\end{array}$ & Russia, Putorana, Fedosov 18-01-0007 MW, isolate Hyl8 & MK463516 \\
\hline $\begin{array}{l}\text { Hylocomium splendens var. } \\
\text { obtusifolium }\end{array}$ & Russia, Putorana, Fedosov 18-01-0006 MW, isolate Hyl7 & MK463517 \\
\hline Rhytidiadelphus loreus & Germany, Ignatov 16-2017 MHA, isolate OK2081 & MK463518 \\
\hline Rhytidiadelphus loreus & $\begin{array}{l}\text { Norway, Ignatov and Ignatova 06-5048 MHA 9057396, isolate } \\
\text { OK2085 }\end{array}$ & MK463519 \\
\hline Rhytidiadelphus japonicus & Russia, Kunashir, Ignatov 06-1059 MHA 9049037, isolate 2086 & MK463520 \\
\hline Rhytidiadelphus japonicus & Russia, Sakhalin, Fedosov 8 Aug 2014, MW, isolate RF9 & MK463521 \\
\hline Rhytidiadelphus japonicus & $\begin{array}{l}\text { Russia, Khabarovsk, Ignatov and Ignatova 13-1227 MW, isolate } \\
\text { FR2 }\end{array}$ & MK463522 \\
\hline Rhytidiadelphus japonicus & $\begin{array}{l}\text { Russia, Kuril Islands, Iturup, Fedosov } 21 \text { Sept } 2015 \text { MW, isolate } \\
\text { FR1 }\end{array}$ & MK463523 \\
\hline Rhytidiadelphus japonicus & Russia, Commander Islands, Bakalin 10-3-558 MW, isolate FR6 & MK463524 \\
\hline Rhytidiadelphus subpinnatus & $\begin{array}{l}\text { Russia, Sakhalin, Ignatov and Teleganova, 06-354 MW, isolate } \\
\text { FR5 }\end{array}$ & MK463525 \\
\hline Rhytidiadelphus subpinnatus & $\begin{array}{l}\text { Russia, Khanty-Mansi Autonomous District, Lapshina 13-86 } \\
\text { MHA, isolate OK1928 }\end{array}$ & MK463526 \\
\hline Rhytidiadelphus subpinnatus & Russia, Kunashir, Ignatov 06-1816 MHA, isolate OK1929 & MK463527 \\
\hline Rhytidiadelphus subpinnatus & $\begin{array}{l}\text { Russia, Kamchatka, Fedosov, 12-107 MW 9063386, isolate } \\
\text { OK2025 }\end{array}$ & MK463528 \\
\hline Rhytidiadelphus pacificus & Russia, Kunashir,Koroteeva 15-12-8 MHA, isolate OK1861 & MK463529 \\
\hline Rhytidiadelphus pacificus & Russia, Kunashir, Ignatov 06-3207 MHA, isolate OK1862 & MK463530 \\
\hline Rhytidiadelphus pacificus & Russia, Kunashir, Koroteeva 15-12-1 MHA, isolate OK1925 & MK463531 \\
\hline Rhytidiadelphus pacificus & USA, Oregon, Norris 83956 MHA9057426, isolate OK1826 & MK463532 \\
\hline Rhytidiadelphus squarrosus & Russia, Ivanovo, Sorokin 27-6-2008 MHA, isolate OK1864 & MK463533 \\
\hline Rhytidiadelphus squarrosus & $\begin{array}{l}\text { Russia, Commander Islands, Fedosov, 10-3-286 MW } 9063387 \text {, } \\
\text { isolate OK2026 }\end{array}$ & MK463534 \\
\hline
\end{tabular}

